\title{
SURVEYS OF WILD VERTEBRATES IN THE KHARGA AND DAKHLA OASIS AND THEIR IMPACT ON THE NEW RECLAMATION AREAS IN EGYPT
}

\author{
Eman M.E. Mohallal ${ }^{1 *}$ and Hany A.A. Ahmed ${ }^{2}$ \\ ${ }^{1}$ Ecology Unit of Desert Animals, Desert Research Centre, El \\ Matareya, Cairo, Egypt \\ ${ }^{2}$ Department of Agricultural Harmful Animals, Plant Protection \\ Research Institute, Agricultural Research Center, Dokki, Giza, Egypt \\ *E-mail: emanmohallal@yahoo.com
}

urvey of the wild vertebrates at twenty-nine locations in
Kharga and Dakhla Oases were carried out during 2014-
2018 , inclusive. Thirty-five common species were recorded. There was one reptile, the Horned Viper. There were twenty-two birds representing twelve orders: eight are common resident species, and the rest are migrants. There were twelve mammals, including two carnivores, eight rodents and two bats. Regular surveys of vertebrates are needed to evaluate the effect of human activities in the new reclamation areas, and to update different lists of reptiles, birds and mammals. Some adverse effects of rats and various birds (House Sparrow, Palm Dove) as well as of Fruit Bats were recorded, because they eat seeds and fruits during the harvest season.

Keywords: wild vertebrates, Kharga and Dakhla Oasis, new reclamation areas

In recent years, the wild vertebrate fauna of Egypt has become threatened by a variety of human activities; including the expanding human population, direct hunting, ecotourism, industrial and agricultural development and urbanization (Hoath, 2003 and Soliman and Mohallal, 2014). Research on birds in cities worldwide has been steadily accumulating, particularly over the last few decades, and results indicate that as development intensifies, bird communities become increasingly homogenized (McKinney and Lockwood, 1999).

The New Valley Governorate is in the south-western part of Egypt, and occupies $44 \%$ of Egypt's area, sharing the international borders of Libya to the west and Sudan to the south. Kharga and Dakhla Oases are considered 
to be a target for government development in the New Valley Governorate (EEAA, 2014).

Development activities can result in the disappearance of local species or the introduction of alien ones (Soliman and Mohallal, 2016). Regular surveys of vertebrates are thus needed to evaluate the effect of such human activities, and to update the lists of reptiles, birds and mammals of the different natural habitats of Egypt. Updated lists of extant species are important for wildlife conservationists, public health authorities, and vertebrate pest managers.

There are few published works on the fauna of these oases. Almost forty years ago, Osborn and Helmy (1980) published a comprehensive work that treated the taxonomy, distribution and biology of Egyptian mammals, including those of Kharga and Dakhla. Goodman and Meininger (1989) summarized what were known about the birds of the Egyptian Western Desert, including Kharga and Dakhla. Since those dates, as far as we are aware, no large-scale surveys of the wild vertebrates of the oases have been published. Expanding agricultural development and active ecotourism make such a survey an important task.

\section{MATERIALS AND METHODS}

\section{Study Area}

There are six different habitats recognized in Kharga and Dakhla oases: sand plains, sand dunes, wasteland, cultivated land, salt marsh and aquatic habitats (Migahid et al., 1960). The present work was carried out through the years 2014, 2017 and 2018 to cover a variety of different localities (Fig. 1).

\section{Survey and Identification of Specimens}

Sampling of the species was largely carried out in 29 localities (Table 1), representing the various habitat types of the oases and neighbouring areas. The latitudes and longitudes of the localities were determined by a hand-held GPS device. The surveys used live traps, as well as observations of tracks and burrow openings, sightings and verbal information collected from trustworthy local people. The reptiles were identified according to Saleh (1997) and Baha El Din (2006). The birds were identified according to Tharwat (1997) and Porter and Cartridge (2009), while mammals were identified according to Osborn and Helmy (1980) and Qumsiyeh (1985). 


\section{RESULTS AND DISCUSSION}

During the study period, one reptile, 22 birds (Table 2), and 12 Mammalia (Table 3) species were recorded from different localities in two oases.

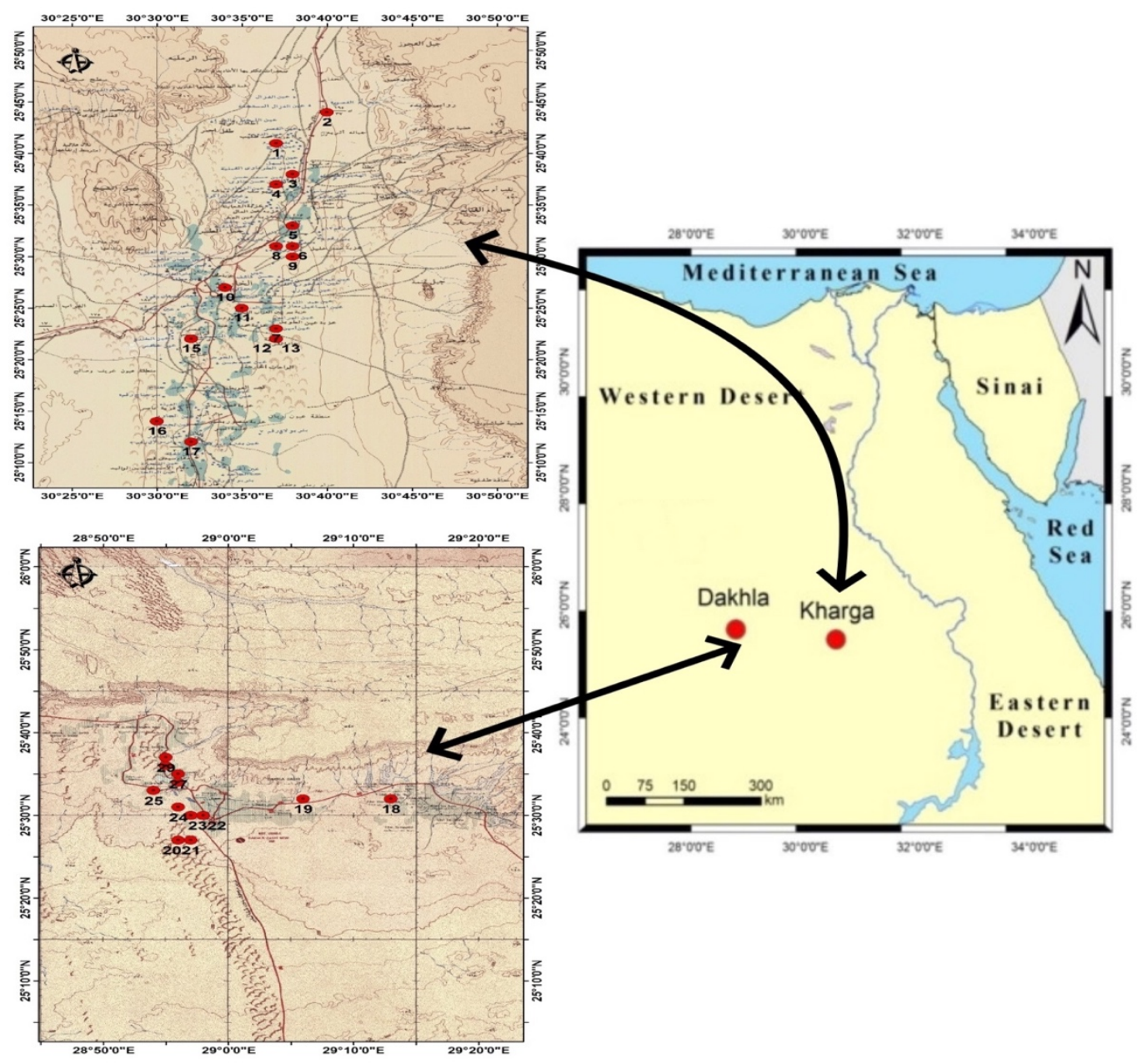

Fig. (1). The survey localities in Kharga and Dakhla Oases. 
Table (1). The survey localities in Kharga and Dakhla oases.

\begin{tabular}{cccccc}
\hline \multicolumn{5}{c}{ Locality } \\
\hline \multicolumn{5}{c}{ Kharga } & \multicolumn{3}{c}{ Dakhla } \\
\hline No. & N lat. & E long. & No. & N lat. & E long. \\
\hline 1 & $25^{\circ} 41^{\prime}$ & $30^{\circ} 37^{\prime}$ & 18 & $25^{\circ} 32^{\prime}$ & $29^{\circ} 13^{\prime}$ \\
2 & $25^{\circ} 44^{\prime}$ & $30^{\circ} 40^{\prime}$ & 19 & $25^{\circ} 32^{\prime}$ & $29^{\circ} 06^{\prime}$ \\
3 & $25^{\circ} 38^{\prime}$ & $30^{\circ} 38^{\prime}$ & 20 & $25^{\circ} 27^{\prime}$ & $28^{\circ} 59^{\prime}$ \\
4 & $25^{\circ} 37^{\prime}$ & $30^{\circ} 37^{\prime}$ & 21 & $25^{\circ} 27^{\prime}$ & $28^{\circ} 57^{\prime}$ \\
5 & $25^{\circ} 33^{\prime}$ & $30^{\circ} 38^{\prime}$ & 22 & $25^{\circ} 30^{\prime}$ & $28^{\circ} 58^{\prime}$ \\
6 & $25^{\circ} 31^{\prime}$ & $30^{\circ} 38^{\prime}$ & 23 & $25^{\circ} 30^{\prime}$ & $28^{\circ} 57^{\prime}$ \\
7 & $25^{\circ} 23^{\prime}$ & $30^{\circ} 37^{\prime}$ & 24 & $25^{\circ} 31^{\prime}$ & $28^{\circ} 56^{\prime}$ \\
8 & $25^{\circ} 31^{\prime}$ & $30^{\circ} 37^{\prime}$ & 25 & $25^{\circ} 33^{\prime}$ & $28^{\circ} 54^{\prime}$ \\
9 & $25^{\circ} 30^{\prime}$ & $30^{\circ} 38^{\prime}$ & 26 & $25^{\circ} 34^{\prime}$ & $28^{\circ} 56^{\prime}$ \\
10 & $25^{\circ} 27^{\prime}$ & $30^{\circ} 34^{\prime}$ & 27 & $25^{\circ} 35^{\prime}$ & $28^{\circ} 56^{\prime}$ \\
11 & $25^{\circ} 25^{\prime}$ & $30^{\circ} 35^{\prime}$ & 28 & $25^{\circ} 36^{\prime}$ & $28^{\circ} 55^{\prime}$ \\
12 & $25^{\circ} 25^{\prime}$ & $30^{\circ} 37^{\prime}$ & 29 & $25^{\circ} 37^{\prime}$ & $28^{\circ} 55^{\prime}$ \\
13 & $25^{\circ} 22^{\prime}$ & $30^{\circ} 37^{\prime}$ & & & \\
14 & $25^{\circ} 22^{\prime}$ & $30^{\circ} 32^{\prime}$ & & \\
15 & $25^{\circ} 22^{\prime}$ & $30^{\circ} 32^{\prime}$ & & \\
16 & $25^{\circ} 14^{\prime}$ & $30^{\circ} 30^{\prime}$ & & & \\
17 & $25^{\circ} 12^{\prime}$ & $30^{\circ} 32^{\prime}$ & & & \\
\hline \multicolumn{7}{c}{}
\end{tabular}

The reptile was the Horned Viper Cerastes cerastes (Linnaeus, 1758), a member of the family Viperidae. It is the most common snake in the Egyptian Western Desert (Saleh, 1997 and Baha El Din, 2006). It is nocturnal and a snake of the true desert, preferring sandy soil with some vegetation for shelter. Among the most studied of snakes, Horned Vipers are generally recognized as opportunistic predators with a varied diet (AlSadoon and Paray, 2016), confirmed in this study (Fig. 2) from collections, tracks and information from local people: some were found in new cultivated areas.

The Horned Viper has not yet been assessed for the IUCN Red List (2018). Although this species inhabits some of the harshest environments, its population numbers are stable and the species is not considered threatened. But like many other snakes, habitat destruction, over-collection (for venom extraction), pollution and the introduction of invasive species have had a negative impact on them. In Egypt, there are 1000-10,000 incidences of snakebite per year with about 11-100 deaths (Kasturiratne et al., 2008). Cerastes cerastes has a wide distribution and can be considered the most dangerous viper of the Middle East and North Africa (Saleh, 1997).

Egyptian J. Desert Res., 68, No. 2, 259-276 (2018) 
Table (2). Birds recorded from Kharga and Dakhla oases.

\begin{tabular}{|c|c|c|c|c|c|c|c|c|}
\hline Class & Order & Family & Genus & Species & $\begin{array}{l}\text { Common } \\
\text { name }\end{array}$ & $\begin{array}{l}\text { Red } \\
\text { list }\end{array}$ & $\begin{array}{l}\text { Population } \\
\text { trend }\end{array}$ & Notes \\
\hline \multirow{23}{*}{$\frac{\tilde{V}}{\nabla}$} & & & Elanus & $\begin{array}{l}\text { Elanus } \\
\text { caerruleus }\end{array}$ & $\begin{array}{l}\text { Black- } \\
\text { winged }\end{array}$ & \multirow{23}{*}{ 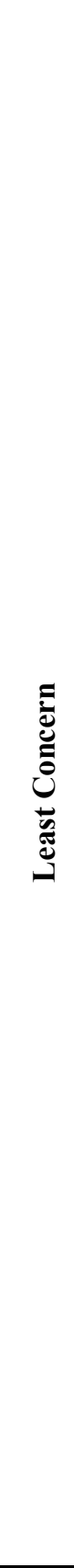 } & unknown & $\begin{array}{l}\text { Common } \\
\text { resident }\end{array}$ \\
\hline & Accipitriformes & Accipitridae & Milvus & $\begin{array}{l}\text { Milvus } \\
\text { migrans }\end{array}$ & $\begin{array}{l}\text { Black } \\
\text { kite }\end{array}$ & & unknown & $\begin{array}{l}\text { Full } \\
\text { migrant }\end{array}$ \\
\hline & rotiformes & & & Upupa & Common & & \multirow{2}{*}{ decreasing } & Full \\
\hline & sucerouformes & орирьаaе & чрира & epops & Hoopoe & & & Migrant \\
\hline & \multirow{2}{*}{ Charadriiformes } & Charadriidae & Vanellus & $\begin{array}{l}\text { Vanellus } \\
\text { spinosus }\end{array}$ & $\begin{array}{l}\text { Spur- } \\
\text { winged }\end{array}$ & & increasing & $\begin{array}{l}\text { Full } \\
\text { migrant }\end{array}$ \\
\hline & & Recurvirostridae & Himantopus & $\begin{array}{l}\text { Himantopus } \\
\text { himantopus }\end{array}$ & $\begin{array}{l}\text { black- } \\
\text { winged }\end{array}$ & & increasing & $\begin{array}{l}\text { Full } \\
\text { migrant }\end{array}$ \\
\hline & \multirow{3}{*}{ Columbiformes } & \multirow{3}{*}{ Columbidae } & Streptopelia & $\begin{array}{l}\text { Streptopelia } \\
\text { deacaocto }\end{array}$ & $\begin{array}{l}\text { Eurasian } \\
\text { collared }\end{array}$ & & unknown & $\begin{array}{l}\text { Common } \\
\text { resident }\end{array}$ \\
\hline & & & Columba & $\begin{array}{l}\text { Columba } \\
\text { livia }\end{array}$ & $\begin{array}{l}\text { Rock } \\
\text { Pigeon }\end{array}$ & & decreasing & $\begin{array}{l}\text { Common } \\
\text { resident }\end{array}$ \\
\hline & & & Spilopelia & $\begin{array}{l}\text { Streptopelia } \\
\text { senegalensis }\end{array}$ & $\begin{array}{l}\text { palm } \\
\text { Dove }\end{array}$ & & stable & $\begin{array}{l}\text { Full } \\
\text { migrant }\end{array}$ \\
\hline & \multirow{2}{*}{ Coraciiformes } & Meropidae & Merops & $\begin{array}{l}\text { Merops } \\
\text { persicus }\end{array}$ & $\begin{array}{l}\text { Blue- } \\
\text { cheeked }\end{array}$ & & stable & $\begin{array}{l}\text { Full } \\
\text { Migrant }\end{array}$ \\
\hline & & Alcedinidae & Ceryle & Ceryle rudis & $\begin{array}{l}\text { pied } \\
\text { kingfisher }\end{array}$ & & unknown & $\begin{array}{l}\text { Common } \\
\text { resident }\end{array}$ \\
\hline & Galliformes & Phasianidae & Coturnix & $\begin{array}{l}\text { Coturnix } \\
\text { Coturnix }\end{array}$ & $\begin{array}{l}\text { Common } \\
\text { Quail }\end{array}$ & & decreasing & $\begin{array}{l}\text { Full } \\
\text { migrant }\end{array}$ \\
\hline & \multirow{2}{*}{ Gruiformes } & \multirow{2}{*}{ Rallidae } & Gallinula & $\begin{array}{l}\text { Gallinula } \\
\text { chloropus }\end{array}$ & $\begin{array}{l}\text { Commen } \\
\text { Moorhen }\end{array}$ & & stable & $\begin{array}{l}\text { Full } \\
\text { migrant }\end{array}$ \\
\hline & & & Fulica & Fulica atra & $\begin{array}{l}\text { Eurasian } \\
\text { Coot }\end{array}$ & & increasing & $\begin{array}{l}\text { Full } \\
\text { migrant }\end{array}$ \\
\hline & \multirow{4}{*}{ Passeriformes } & Passeridae & Passer & $\begin{array}{l}\text { Passer } \\
\text { domesticus }\end{array}$ & $\begin{array}{l}\text { House } \\
\text { Sparrow }\end{array}$ & & decreasing & $\begin{array}{l}\text { Common } \\
\text { resident }\end{array}$ \\
\hline & & Corvidae & Corvus & $\begin{array}{l}\text { Corvus } \\
\text { ruficollis }\end{array}$ & $\begin{array}{l}\text { Brown- } \\
\text { necked }\end{array}$ & & increasing & $\begin{array}{l}\text { Common } \\
\text { resident }\end{array}$ \\
\hline & & Motacillidae & Motacilla & $\begin{array}{l}\text { Motacilla } \\
\text { alba }\end{array}$ & $\begin{array}{l}\text { White } \\
\text { wagtail }\end{array}$ & & stable & $\begin{array}{l}\text { Full } \\
\text { migrant }\end{array}$ \\
\hline & & Alaudidae & Ammomanes & $\begin{array}{l}\text { Ammomanes } \\
\text { cincturus }\end{array}$ & $\begin{array}{l}\text { Bar-tailed } \\
\text { desert }\end{array}$ & & decreasing & $\begin{array}{l}\text { Common } \\
\text { resident }\end{array}$ \\
\hline & \multirow{3}{*}{ Pelecaniformes } & \multirow{3}{*}{ Ardeidae } & Bubulcus & $\begin{array}{l}\text { Bubulcus } \\
\text { ibis }\end{array}$ & $\begin{array}{l}\text { Cattle } \\
\text { Egret }\end{array}$ & & increasing & $\begin{array}{l}\text { Full } \\
\text { migrant }\end{array}$ \\
\hline & & & Egretta & $\begin{array}{l}\text { Egretta } \\
\text { garzetta }\end{array}$ & $\begin{array}{l}\text { Little } \\
\text { Egret }\end{array}$ & & increasing & $\begin{array}{l}\text { Full } \\
\text { migrant }\end{array}$ \\
\hline & & & Ardeola & $\begin{array}{l}\text { Ardeola } \\
\text { ralloides }\end{array}$ & $\begin{array}{l}\text { Squacco } \\
\text { heron }\end{array}$ & & Unknown & $\begin{array}{l}\text { Full } \\
\text { migrant }\end{array}$ \\
\hline & Podicipediformes & Podicipedidae & Tachybaptus & $\begin{array}{l}\text { Tachybaptus } \\
\text { ruficollis }\end{array}$ & $\begin{array}{l}\text { little } \\
\text { grebe }\end{array}$ & & decreasing & $\begin{array}{l}\text { Full } \\
\text { migrant }\end{array}$ \\
\hline & Strigiformes & Strigidae & Athene & $\begin{array}{l}\text { Athene } \\
\text { noctua }\end{array}$ & Little owl & & stable & $\begin{array}{l}\text { Common } \\
\text { resident }\end{array}$ \\
\hline
\end{tabular}


Table (3). Mammals recorded from Kharga and Dakhla Oases.

\begin{tabular}{|c|c|c|c|c|c|c|c|}
\hline Class & Order & Family & Genus & Species & $\begin{array}{c}\text { Common } \\
\text { name }\end{array}$ & Red list & $\begin{array}{c}\text { Population } \\
\text { trend }\end{array}$ \\
\hline \multirow{11}{*}{ 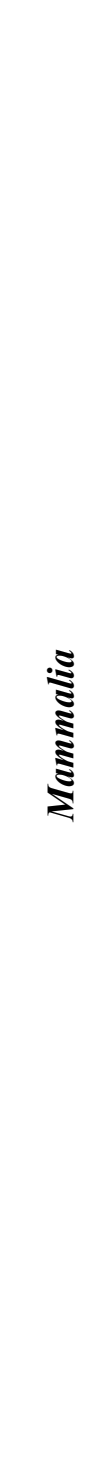 } & \multirow{2}{*}{ Carnivora } & \multirow{2}{*}{ Canidae } & Vulpes & $\begin{array}{l}\text { Vulpes } \\
\text { vulpes }\end{array}$ & Red fox & $\begin{array}{c}\text { Least } \\
\text { Concern }\end{array}$ & stable \\
\hline & & & Canis & $\begin{array}{c}\text { Canis } \\
\text { lupaster }\end{array}$ & $\begin{array}{l}\text { Egyptian } \\
\text { wolf }\end{array}$ & Unknown & Unknown \\
\hline & \multirow{7}{*}{ Rodentia } & \multirow{7}{*}{ Muridae } & Acomys & $\begin{array}{l}\text { Acomys } \\
\text { cahirinus }\end{array}$ & $\begin{array}{l}\text { Cairo } \\
\text { spiny }\end{array}$ & \multirow{7}{*}{$\begin{array}{c}\text { Least } \\
\text { Concern }\end{array}$} & stable \\
\hline & & & Rattus & $\begin{array}{c}\text { Rattus } \\
\text { rattus } \\
\text { Rattus } \\
\text { norvegicus }\end{array}$ & $\begin{array}{l}\text { black rate } \\
\text { brown rat }\end{array}$ & & $\begin{array}{l}\text { stable } \\
\text { stable }\end{array}$ \\
\hline & & & & $\begin{array}{c}\text { Gerbillus } \\
\text { pyramidum }\end{array}$ & $\begin{array}{l}\text { Greater } \\
\text { Egyptian } \\
\text { gerbil }\end{array}$ & & stable \\
\hline & & & Gerbillus & $\begin{array}{l}\text { Gerbillus } \\
\text { gerbillus }\end{array}$ & $\begin{array}{l}\text { Lesser } \\
\text { Egyptian } \\
\text { gerbil }\end{array}$ & & stable \\
\hline & & & & $\begin{array}{l}\text { Dipodillus } \\
\text { campestris }\end{array}$ & $\begin{array}{c}\text { North } \\
\text { African } \\
\text { gerbil }\end{array}$ & & Unknown \\
\hline & & & \multirow{2}{*}{ Meriones } & $\begin{array}{l}\text { Meriones } \\
\text { libycus }\end{array}$ & $\begin{array}{c}\text { The } \\
\text { Libyan jird }\end{array}$ & & stable \\
\hline & & & & $\begin{array}{c}\text { Meriones } \\
\text { crassus }\end{array}$ & $\begin{array}{c}\text { Sundevall's } \\
\text { jird, }\end{array}$ & & Unknown \\
\hline & \multirow[b]{2}{*}{ Chiroptera } & Pteropodidae & Rousettus & $\begin{array}{l}\text { Rousettus } \\
\text { aegyptiacus }\end{array}$ & $\begin{array}{l}\text { Egyptian } \\
\text { fruit bat }\end{array}$ & \multirow{2}{*}{$\begin{array}{c}\text { Least } \\
\text { Concern }\end{array}$} & stable \\
\hline & & Hipposideridae & Asellia & $\begin{array}{l}\text { Asellia } \\
\text { tridens }\end{array}$ & $\begin{array}{l}\text { Trident } \\
\text { leaf-nosed } \\
\text { bat }\end{array}$ & & stable \\
\hline
\end{tabular}

Egyptian J. Desert Res., 68, No. 2, 259-276 (2018) 


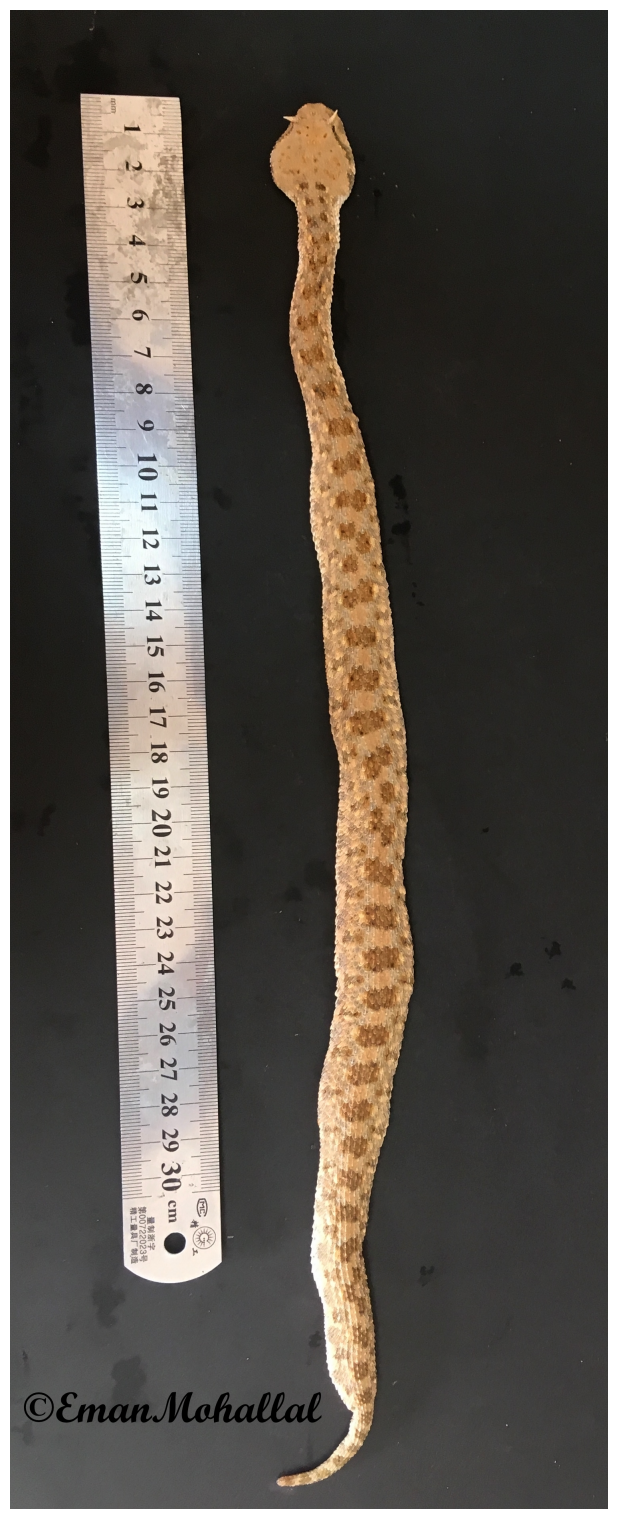

Fig. (2). A Horned Viper collected by a local man in Kharga.

\section{Birds}

Twenty- two common bird species were recorded during the whole period of the study. There were eight common resident species, and the others were full migrants (Table 2). The common birds in the area (Plate 1) were Black-winged Kite, Black Kite, Common Hoopoe, Spur-winged Plover, Black-winged Stilt, Eurasian Collared Dove, Rock Pigeon, Palm Egyptian J. Desert Res., 68, No. 2, 259-276 (2018) 
Dove, Blue-cheeked Bee-eater, Pied Kingfisher, Common Quail, Common Moorhen, Eurasian Coot, House Sparrow, Brown-necked Raven, White Wagtail, Bar-tailed Desert Lark, Cattle Egret, Little Egret, Squacco Heron, Little Grebe and Little Owl. These birds were recorded from various habitats in the oases. Areas with trees and bushes, especially where associated with water, held many birds (Porter and Cottridge, 2001).

Many species are of economic importance, mostly as sources of food acquired through hunting or farming. Other uses include the harvesting of guano (droppings) for use as a fertilizer. Some birds can act as vectors for spreading diseases (Benskin et al., 2009). For example, the House Sparrow is often considered a pest (Plate 2) owing to concerns that they spread diseases in their feces, such as psittacosis and salmonellosis, and eat seeds during harvest seasons. Sustainable development requires the reconciliation of demands for biodiversity conservation and increased agricultural production. Assessing the impact of novel farming practices on biodiversity and ecosystem services is fundamental to this process. Awadallah et al. (2013) mention that Cattle Egrets play a major role in the natural selection process and in controlling agricultural and domestic pests; such as rodents, molluscs and arthropods. Knowledge of species diversity across a landscape is essential for answering such ecological questions and developing conservation and management goals and protocols. However, data on species occurrence are often limited (Lepczyk, 2005).

The diet of the House Sparrow is mainly vegetable material, particularly seeds of grasses, cultivated cereals and low herbs, but also buds, berries and a wide range of household scraps. The Palm Dove feeds on small seeds, but also takes fruits, nectar from Aloe and some insects. The Eurasian Coot is omnivorous, although its diet consists primarily of vegetable matter such as algae, aquatic and terrestrial plant pests (e.g. waterweeds, bulrushes, reeds and grasses), the seeds of waterweeds, sedges, water-lilies, grasses and cereal crops (del Hoyo et al., 1996) and small fish (Urban et al., 1986 and del Hoyo et al., 1996).

\section{Mammals}

Many Red Foxes Vulpes vulpes were recorded before sunset in new farmland and also in desert areas (Fig. 3). The Red Fox is widely distributed in Egypt, having been recorded from various localities of the Western Desert including the Cairo-Alexandria Desert Road, Wadi El-Natroun, El Faiyum, Kharga and Dakhla Oases, as well as the Western Mediterranean Coastal Desert (Flower, 1932; Osborn and Helmy, 1980; Wassif and Soliman, 1993; Hoath, 2003 and Soliman and Mohallal, 2016). It is threatened directly and indirectly by persecution by hunting and the indiscriminate use of poisons. In some regions, foxes face persecution for their perceived impact on livestock (Murdoch et al., 2007).

Egyptian J. Desert Res., 68, No. 2, 259-276 (2018) 
One specimen of the Egyptian wolf Canis lupaster was killed by a local man in the Labkea area of Kharga Oasis (Fig. 4). This is a common wild canid throughout Egypt. Its taxonomic status, particularly its relationship with the Grey Wolf Canis lupus and the Golden Jackal $C$. aureus has been a matter of recent debate (Rueness et al., 2011; Gaubert et al., 2012 and Saleh et al., 2018).

Eight species of rodent (Order: Rodentia) were recorded, including Black Rattus rattus and Brown Rats Rattus norvegicus (Plate 3). These are considered invasive species, and even local people consider them to be big problems to their crops. The archetypal tramp species, invasive rats have spread from their source populations in SE Asia and China across the globe alongside humans and are now found throughout the world (Barnett, 2001 and Aplin et al., 2011). In Egypt, changes to the environment by desert reclamation and increases to plant cover have changed the distribution and abundance of rodents (El-Sherbiny, 1987; Abdel-Gawad, 2010 and Desoky et al., 2014).

Other desert rodents (Plate 3); Gerbillus pyramidum, Gerbillus gerbillus and Dipodillus campestris were only found in the ecotones between farms and desert areas. Meriones libycus and Meriones crassus were found only at the edges of Dakhla oases in new reclamation projects.

Acomys cahirinus (Plate 3) was also collected from farms in Dakhla Oasis near rocky areas, known to be good habitat for them. There are no major threats to this species. It is considered a pest in some areas, as it can feed on crops (Plate 2). Agricultural pestsl; such as birds and rodents can cause significant damage to crops and reduce the ability of growers to provide agricultural commodities to the market (Desoky, 2014).

\section{Bats}

The Egyptian Fruit Bat Rousettus aegyptiacus (Geoffroy, 1810) has a broad habitat tolerance, so long as abundant food and appropriate roosting sites is available (Qumsiyeh, 1985). It was recorded from old houses and gardens in Kharga and Dakhla Oases (Fig. 5). It feeds on soft fruits (date, carob, mulberry, fig, apricot, peach and apple), flowers, occasionally taking leaves, and was observed feeding on flying insects. It often forages in orchards. It roosts in moist natural caverns and artificial structures, including underground irrigation tunnels (ghanats), ruins, tombs, mines, bunkers and open wells. It is considered a pest in some areas because it can feed on fruits and vegetables (Plate 2).

Geoffroy's Trident Leaf-nosed Bat Asellia tridens (Geoffroy, 1813) was recorded from old caves in Kharga and Dakhla Oases (Fig. 6). This is a gregarious and colonial species, which occurs in crevices or in cliffs in arid and semi-desert habitats (Wassif, 1949). It roosts in temples, caves, mines, open wells, underground irrigation tunnels and old tombs and buildings. It is 
forages over desert and semi-desert vegetation zones, mainly in oases. It has been observed foraging around palm trees and over water (Qumsiyeh, 1985).

The main threat to bats is the widespread use of pesticides against locusts. Human disturbance to caves and old buildings is affecting some populations. Threats to bats can be in different forms: ecotourism, entering caves during hibernating season, putting fire and fireworks in caves, as well as shooting (Abi-Said, 2014).

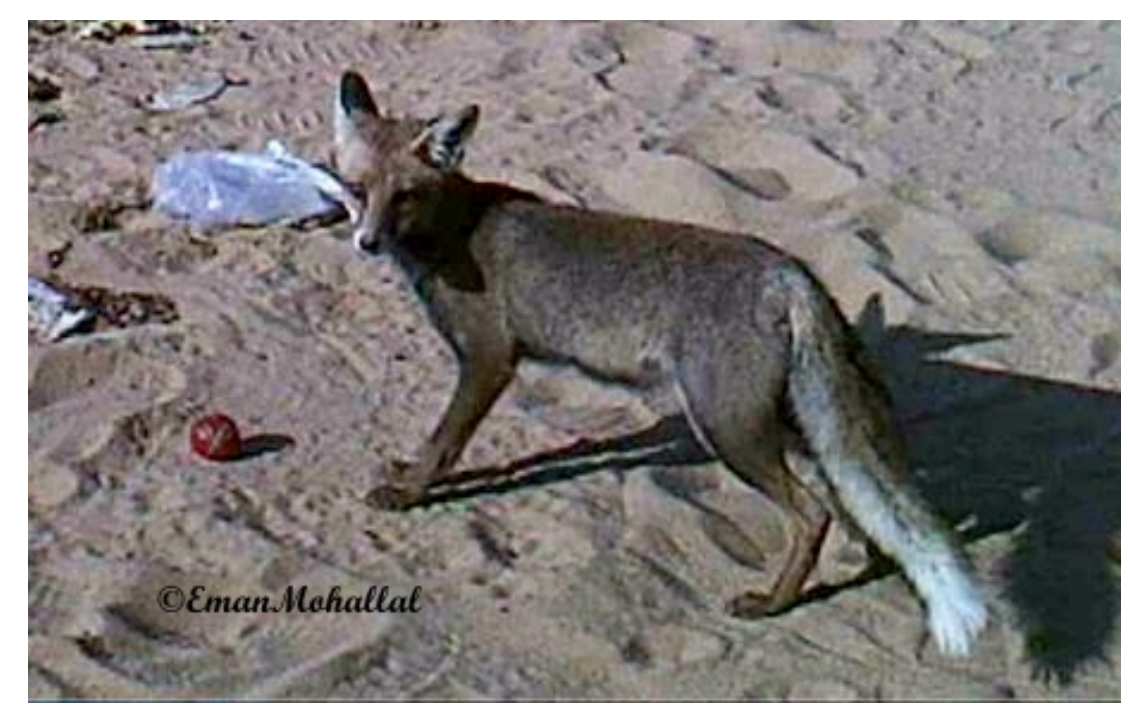

Fig. (3). The Red Fox Vulpes vulpes recorded before sunset in a desert area near new farm lands in Kharga Oasis.

Egyptian J. Desert Res., 68, No. 2, 259-276 (2018) 


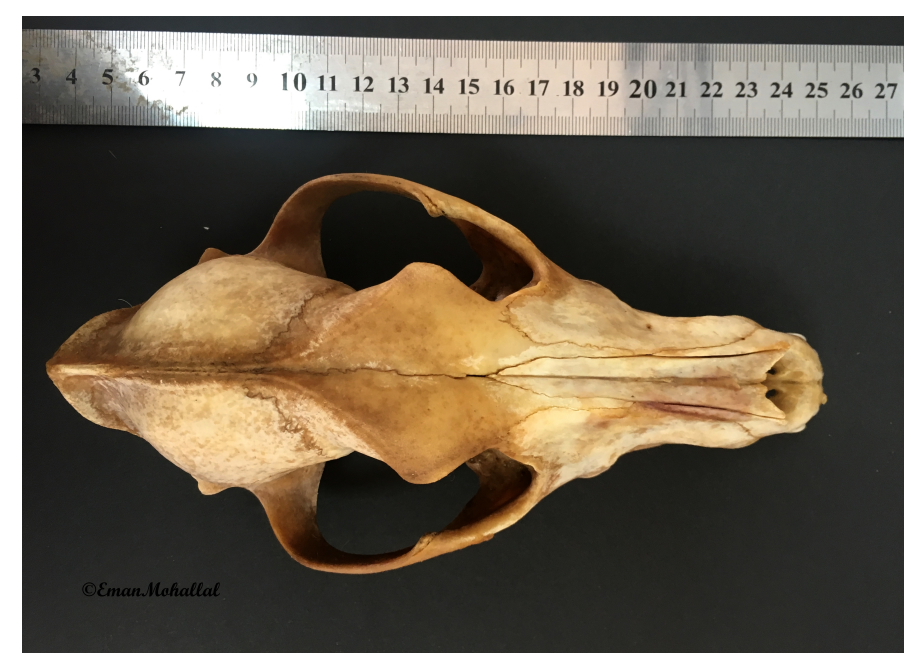

Fig. (4). The skull of a specimen of Canis lupaster killed by a local man in the Labkea area of Kharga Oasis

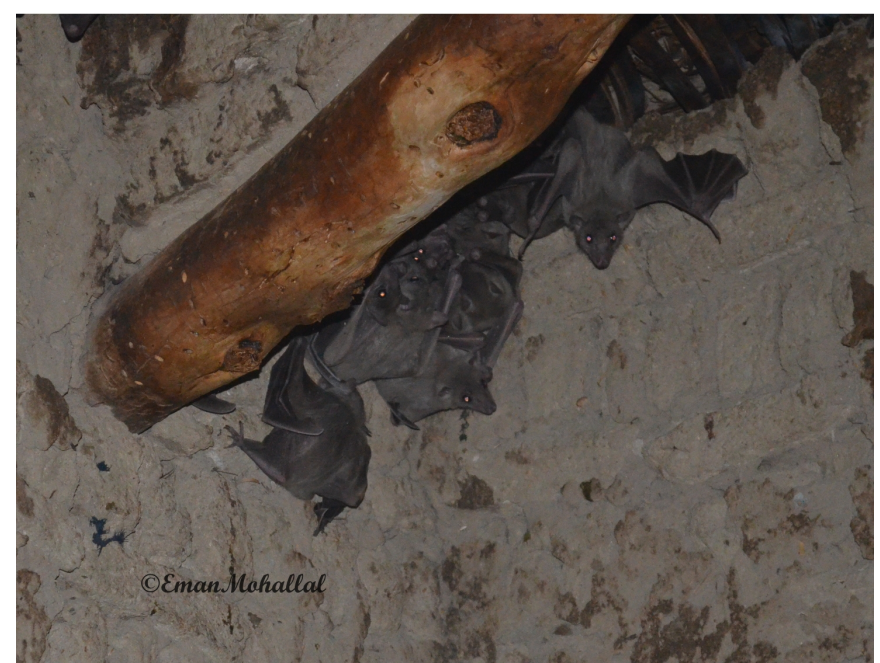

Fig. (5). Rousettus aegyptiacus recorded in an old house in Dakhla Oasis.

Egyptian J. Desert Res., 68, No. 2, 259-276 (2018) 


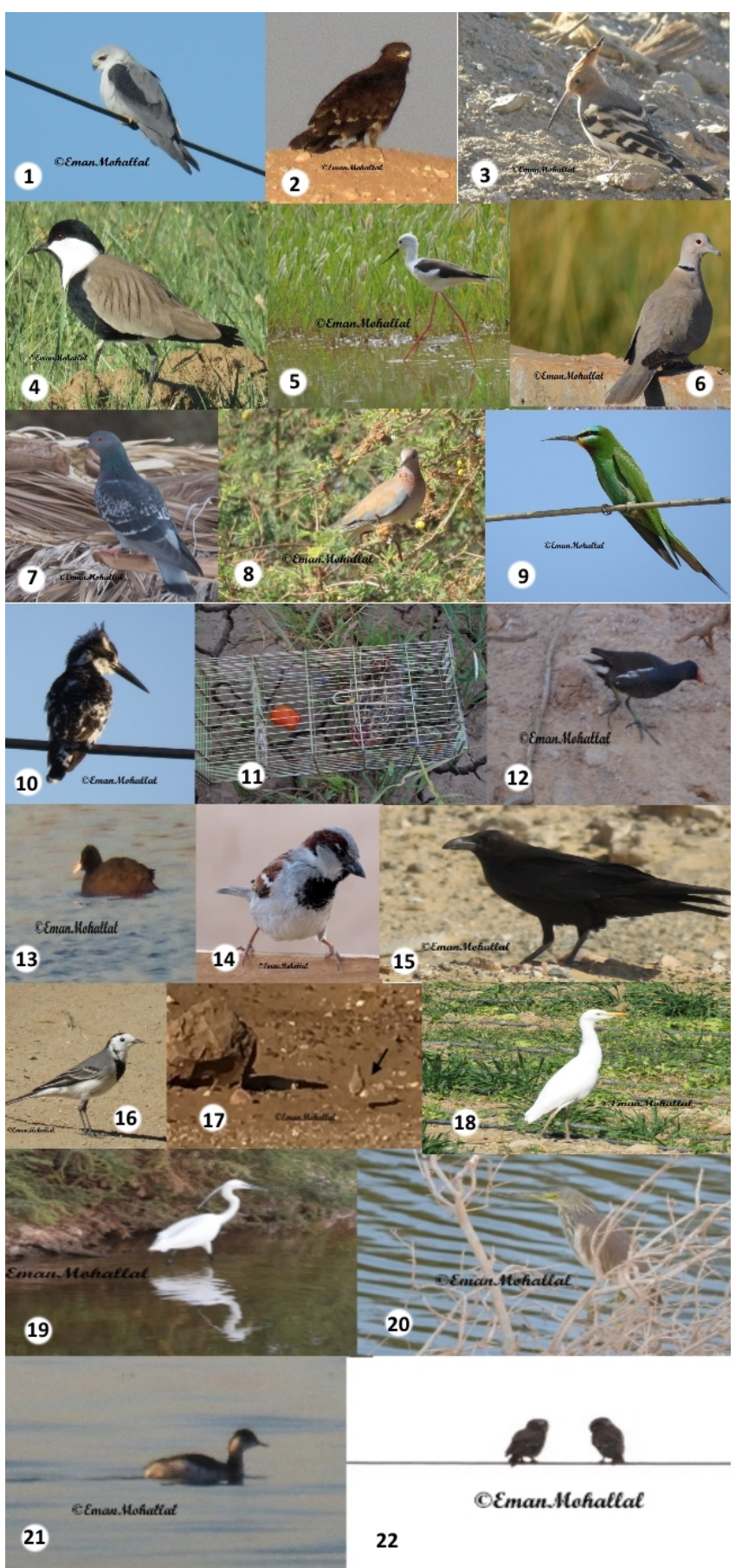

Plate (1). Photos of common birds in Kharga and Dakhla Oases (number as in Table 2).

Egyptian J. Desert Res., 68, No. 2, 259-276 (2018) 


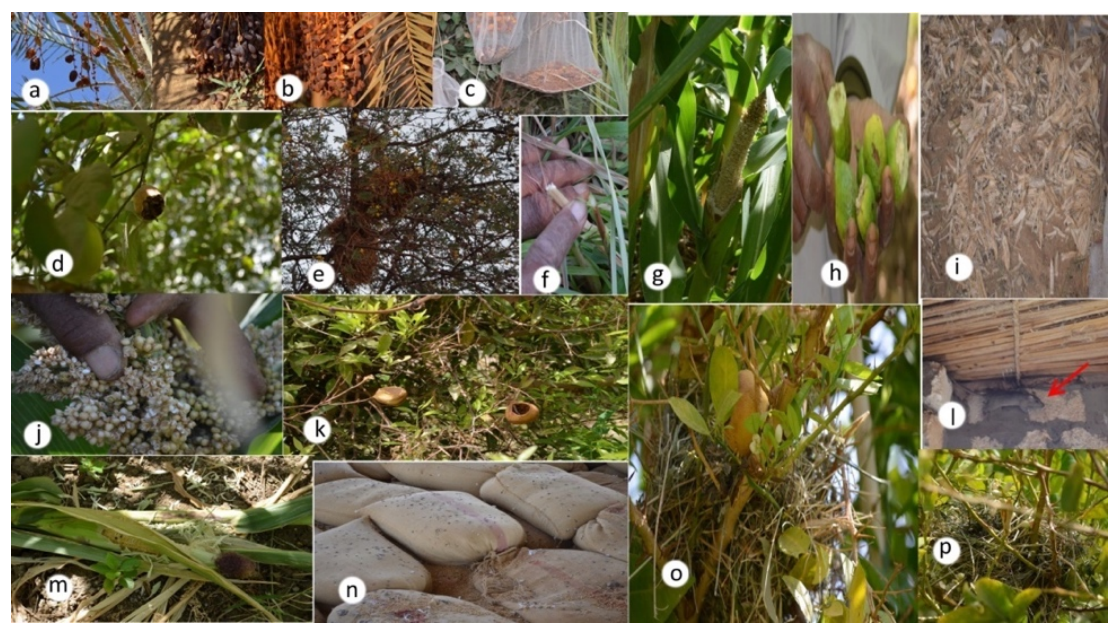

Plate (2). Damage recorded from rodents, birds and fruit bats during the study period.

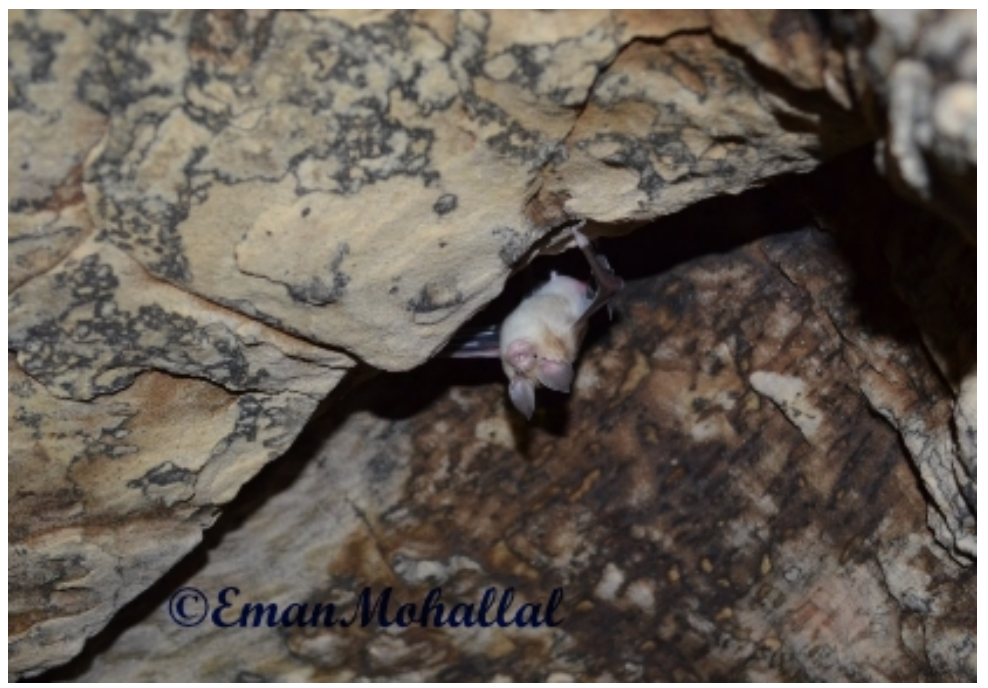

Fig. (6). Asellia tridens recorded in an old cave in Kharga and Dakhla oases. 


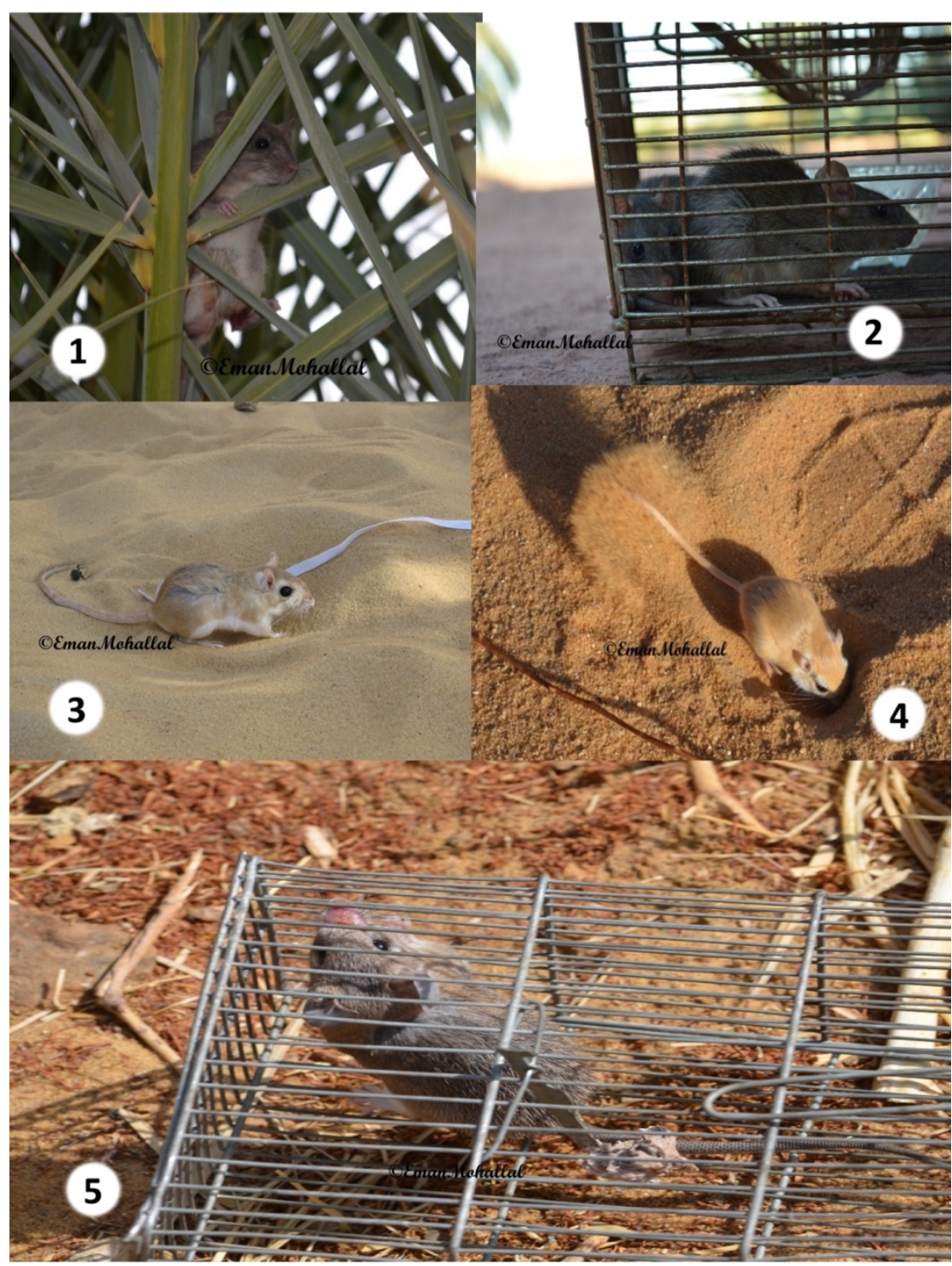

Plate (3). Common rodents from Kharga and Dakhla Oases (numbers as in Table 3). 


\section{REFERENCES}

Abdel-Gawad, K.H. (2010). Rodent species composition in the present compared with past, the $5^{\text {th }}$ Scientific Conferences for Agric. Assiut Univ., pp. 159-167.

Abi-Said, M.R. (2014). Monitoring, threats and conservation of hibernating bats roosts in Lebanon, Jordan Journal of Natural History, 1: 152164.

Al-Sadoon, M.K. and B.A. Paray (2016). Ecological aspects of the horned viper, Cerastes cerastes gasperettii in the central region of Saudi Arabia. Saudi Journal of Biological Sciences, 23: 135-138.

Aplin, K.P., H. Suzuki, A.A. Chinen, R.T. Chesser, J. Ten Have, S.C. Donnellan, J. Austin et al. (2011). Multiple geographic origins of commensalism and complex dispersal history of black rats. PloS One, 6: e26357.

Awadallah, A.M., M.M. Abdallah and R.E. Mohamed (2013). Prevalence of zoonotic Escherichia coli and Salmonellae in wild birds and humans in Egypt with emphasis on RAPD-PCR fingerprinting of E. coli. Global Veterinaria, 11 (6): 781-788.

Baha el Din, S. (2006). In "A Guide to Reptiles and Amphibians of Egypt". Cairo: The American University in Cairo Press. ISBN 9789774249792.

Barnett, S.A. (2001). The Story of Rats: Their Impact on Us, and Our Impact on Them. Crows Nest, NSW, Australia Allen and Unwin.

Benskin, C.M.H., K. Wilson, K. Jones and I.R. Hartley (2009). Bacterial pathogens in wild birds: a review of the frequency and effects of infection. Biological Reviews, 84: 349-373.

Del Hoyo, J., A. Elliott and J. Sargatal (1996). In "Handbook of the Birds of the World". Vol. 3. Hoatzin to Auks. Lynx Editions, Barcelona.

Desoky, A.S.S. (2014). Damage caused by birds and rodent in field crops and their control. J. Glob. Innov. Agric. Soc. Sci., 2 (4): 169-170.

Desoky, A.S.S., S.A.S Baghdad and H.S.K. Ahmed (2014). Population density and seasonal distribution of rodent species at sheep farming in El-kawther region, Sohag governorate, Egyptian J. Plant Prot. Path., Mansoura Univ., 5 (10): 903-907.

El-sherbiny, A.H. (1987). Cyclic fluctuation in rodent population: Review of current researches. Egypt Wild and Not Resources, Vol. 19, 17 pp.

Flower, S.S. (1932). Notes on the recent mammals of Egypt, with a list of the species recorded from the kingdom. Proc. Zool. Soc., London, p. 368-450.

Gaubert, P., C. Bloch, S. Benyacoub, A. Abdelhamid, P. Pagani, C.A. Djagoun, A. Couloux and S. Dufour (2012). Reviving the African wolf Canis lupus lupaster in north and west Africa: a mitochondrial 
lineage ranging more than $6,000 \mathrm{~km}$ wide. PLoS ONE, 7 (8): e42740.

Goodman, S.M. and P.L. Meininger (1989). In "The Birds of Egypt". Oxford University Press. Oxford, UK.

Hoath, R. (2003). In "Field Guide to the Mammals of Egypt". American University in Cairo Press, Cairo, $x v+236$ pp.

Kasturiratne, A., A.R. Wickremasinghe, N. de Silva, N.K. Gunawardena, A. Pathmeswaran et al. (2008). Estimating the global burden of snakebite: A literature analysis. PLoS Med 5: e218.

Lepczyk, C.A. (2005). Integrating published data and citizen science to describe bird diversity across a landscape. Journal of Applied Ecology, 42: 672-677.

McKinney, M. and J. Lockwood (1999). Biotic homogenization: a few winners replacing many modellings based on regional estimates of envenoming and deaths. PloS Med 2008 (5): 1591-604.

Migahid, A.M., A.M. El-Shafei, A.A. Abdel Rahman and M.A. Hammouda (1960). An ecological study of Kharga and Dakhla Oases. Bull. Soc. Géogr. D'Egypte, 33: 279-310.

Murdoch, J.D., C. Drew, I. Barcelo and C. Tourenq (2007). Ruppell's foxes in Al Dhafra, United Arab Emirates. Canid News, 10: 1-6.

Osborn, D.J. and I. Helmy (1980). In "The Contemporary Land Mammals of Egypt (Including Sinai)". Fieldiana Zoology, Field Museum of Natural History, New Series, 5: xix +579 pp.

Porter R. and D. Cottridge (2001). In: "A Photographic Guide to Birds of Egypt and the Middle East". New Holland Publishers, UK. ISBN: 18597-4512-1.

Porter, R. and D. Cottridge (2009). In: "A photographic Guide to Birds of Egypt and the Middle East". The American University in Cairo Press, Cairo-New York, 144 pp.

Qumsiyeh, M.B. (1985). The bats of Egypt. Special Publications, The Museum Texas Tech University, 23: $102 \mathrm{pp}$.

Rueness, E.K., M.G. Asmyhr, C. Sillero-Zubiri, D.W. Macdonald, A. Bekele, A. Atickem and N.C. Stenseth (2011). The cryptic African wolf: Canis aureus lupaster is not a golden jackal and is not endemic to Egypt. PLoS ONE, 6 (1): e16385.

Saleh, M. (1997). In: "Amphibians and Reptiles of Egypt". Published by Publication of National Biodiversity Unit, Egyptian Government.

Saleh, M., M. Younes, A. Basuony, F. Abdel-Hamid, A. Nagy and A. Badry (2018). Distribution and phylogeography of Blanford's Fox, Vulpes cana (Carnivora: Canidae), in Africa and the Middle East. Zoology in the Middle East, 64 (1): 9-26.

Soliman, S. and Eman M.E. Mohallal (2014). A survey of the mammalian fauna of Siwa Oasis, Egypt. Egyptian Journal of Zoology, 61: 1-23.

Egyptian J. Desert Res., 68, No. 2, 259-276 (2018) 
Soliman, S. and Eman M.E. Mohallal (2016). The vertebrate fauna recorded from Northeastern Sinai, Egypt. Egyptian J. Desert Res., 66 (1): 3555.

Tharwat, M.E. (1997). In: "Birds Known to Occur in Egypt". Egyptian Environmental Affairs Agency, Publications of the National Biodiversity Unit, No. 8, vi +204 pp. +20 colored plates +3 indices.

Urban, E.K., C.H. Fry and S. Keith (1986). In: "The birds of Africa". Vol. II. Academic Press, London.

Wassif, K. (1949). Trident bat (Asellia tridens) in the Egyptian oasis of Kharga. Bull. Zool. Soc. Egypt, 8: 9-12.

Wassif, K. and S. Soliman. (1993). Habitat diversity and Egyptian mammals. In: Kassas, M. (ed.). Habitat Diversity: Egypt, Publications of the National Biodiversity Unit, 1: 135-200. Egyptian Environmental Affairs Agency. 
مسح لبعض الفقاريات البرية بالواحات الخارجة والأخلة وتأثثرها على فئى

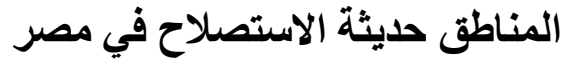

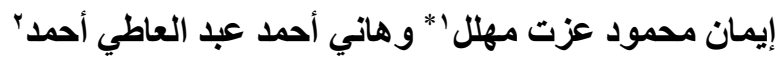

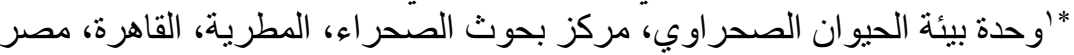

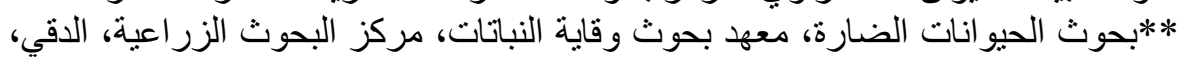
جيزة، مصر

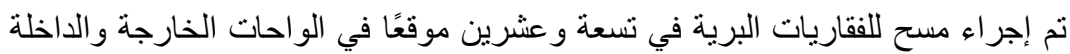

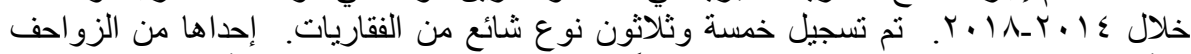

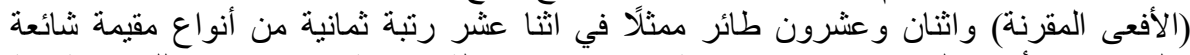

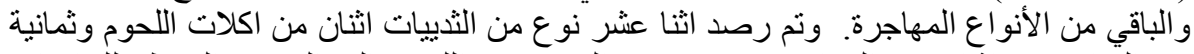

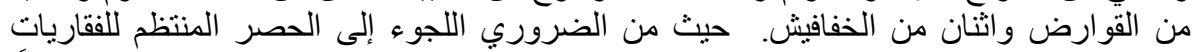

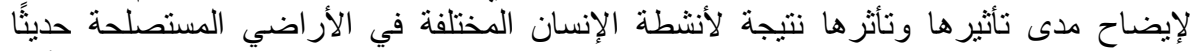

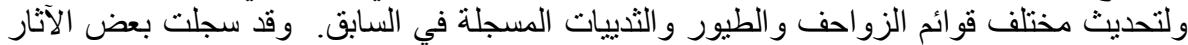

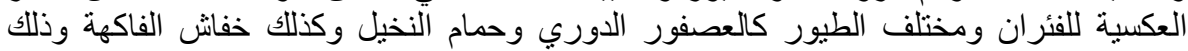
لتغذيتها على البذور و الثنمار خلال موسم الحصاد. 